\title{
Sheep gene mapping by somatic cell hybridization
}

\author{
N Saïdi-Mehtar'1, M Imam-Ghali' ${ }^{1}$, S Heuertz ${ }^{2}$, MC Hors-Cayla² \\ 1 Université d'Oran Es-Sénia, Laboratoire de Biologie Moléculaire et Génétique, \\ Unité de Recherches de Biologie, Algeria; \\ ${ }^{2}$ INSERM U12, Unité de Recherches de Génétique Médicale, Paris, France
}

(Proceedings of the 9th European Colloquium on Cytogenetics of Domestic Animals; Toulouse-Auzeville, 10-13 July 1990)

sheep / ovine / gene mapping / synteny / cell hybrid

\section{INTRODUCTION}

Twenty-five hamster $\times$ sheep hybrid cell lines were previously obtained (SaïdiMehtar et al, 1981b). Analysis of these hybrids has already enabled the identification of 5 syntenic groups and 10 independent markers (Saïdi-Mehtar et al, 1981a, b, 1987; Millot et al, 1981; Imam-Ghali et al, 1987). In this paper, we report results obtained with 3 other enzyme markers: aconitase 1 (ACO1), inosine triphosphatase (ITPA) and glyceraldehyde-3-phosphate dehydrogenase (GAPD); and 6 DNA markers: ornithine transcarbamylase (OTC), color vision red pigment (RCB), raf oncogene (ARAF1) and $\beta$-gene locus DR of human lymphocyte antigen region (HLA-DR $\beta$ ).

\section{ENZYME MARKERS}

ACO1, ITPA and GAPD were studied by cellulose acetate electrophoresis using modified versions of the methods described by Womack and Moll (1986). The cytoplasmic (ACO1) and mitochondrial $(\mathrm{ACO} 2)$ forms of aconitase were identified by successive freezing and thawing of cells followed by electrophoresis of the supernatants. ACO1 was obtained first and corresponded to the most anodal band. A different electrophoretic migration between sheep and hamster was only observed for ACO1. Ovine ITPA migrated more anodally than hamster ITPA. Ovine GAPD is a trimeric enzyme: positive hybrids for sheep GAPD showed 2 intermediate bands (fig 1). Comparison between ACO1, ITPA, GAPD and the other 21 markers previously studied in these hybrids showed 2 syntenic groups. 


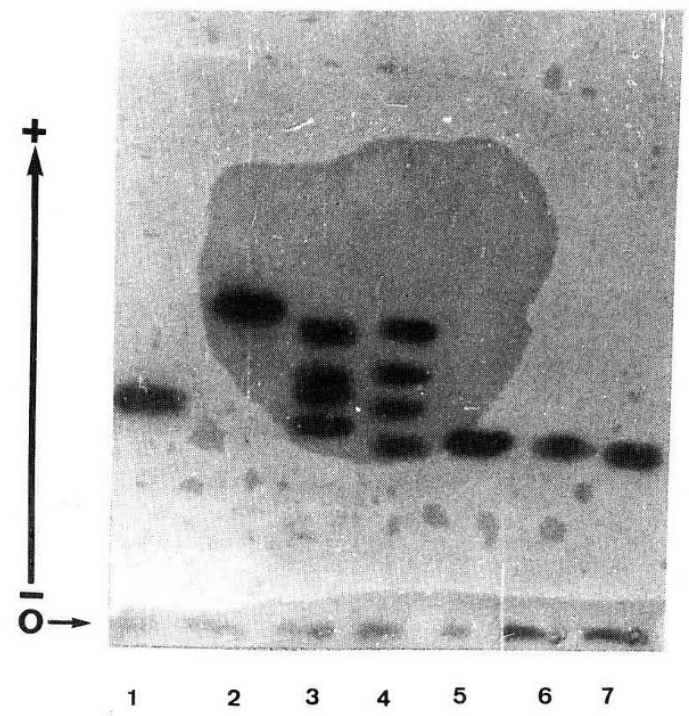

Fig 1. Zymogram of glyceraldehyde-3-phosphate dehydrogenase in Chinese hamster (1), sheep fibroblasts (2), hamster $\times$ sheep hybrids (3-7). The hybrids in lanes 3 and 4 are positive for ovine GAPD and show 2 intermediate bands, the hybrids in lanes 5, 6 and 7 are negative.

\section{ITPA-adenosine deaminase (ADA)}

This synteny is conserved in man (Hopkinson et al, 1976), hamster (Stalling et al, 1982), mouse (Siciliano et al, 1984), cat (Berman et al, 1986), cattle (Womack and Moll, 1986), dog and mink (Human Gene Mapping 9, 1987).

\section{GAPD and lactate dehydrogenase $B$ (LDHB)-peptidase $B$ (PEPB)- triose-phosphate isomerase (TPI)}

This group is syntenic only in man (Bootsma and Ruddle, 1978; Ruddle and Meera Khan, 1976), cattle (Womack and Moll, 1986) and mink (Human Gene Mapping $10,1989)$. This synteny is not conserved in mouse, hamster and rabbit, where an independent segregation is observed between GAPD-TPI-LDHB and PEPB (Human Gene Mapping 10, 1989).

Like ADA, ITPA is on U15. Like LDHB-PEPB-TPI, GAPD is assigned to chromosome 3. ACO1 segregates independently from the other 23 markers and is assigned to U2 (Human Gene Mapping 10, 1989).

\section{DNA MARKERS}

DNA was extracted from the parental hamster cell line, ovine lymphocytes and from 23 hamster $\times$ sheep hybrid lines; 3 hybrid lines were grown concomitantly in hypoxanthine-aminopterine-thymidine (HAT) medium and in 6-thioguanine medium. This DNA was digested with EcoRI and analyzed with the Southern 
blotting technique using the 6 following DNA probes: OTC, isolated by Horwich et al (1984); color vision red pigment, isolated by Nathans et al (1986); one human autosomal probe: HLA-DR $\beta$, isolated by Wiman et al (1982); two rat X-linked probes: brain myelin proteolipoprotein (PLP), isolated by Dautigny et al (1985); synapsin 1, isolated by Kilimann and De Gennaro (1985); and one mouse X-linked probe ARAF1 oncogene, isolated by Huebner et al (1986).

Analysis of hybrids showed: 1) the localization on the sheep $\mathrm{X}$ chromosome of sequences homologous to the following genes: OTC, color vision red pigment, ARAF1 oncogene, brain myelin PLP and synapsin 1 (presence of molecular signals in hybrids grown in HAT medium and absence of signals in the same hybrids grown in 6-thioguanine medium) (fig 2); 2) the absence of a positive correlation between the serological signal obtained with anti-ovine histocompatibility complex (OLA) sera (Millot et al, 1981) and the molecular signal obtained with the HLA-DR $\beta$ probe.

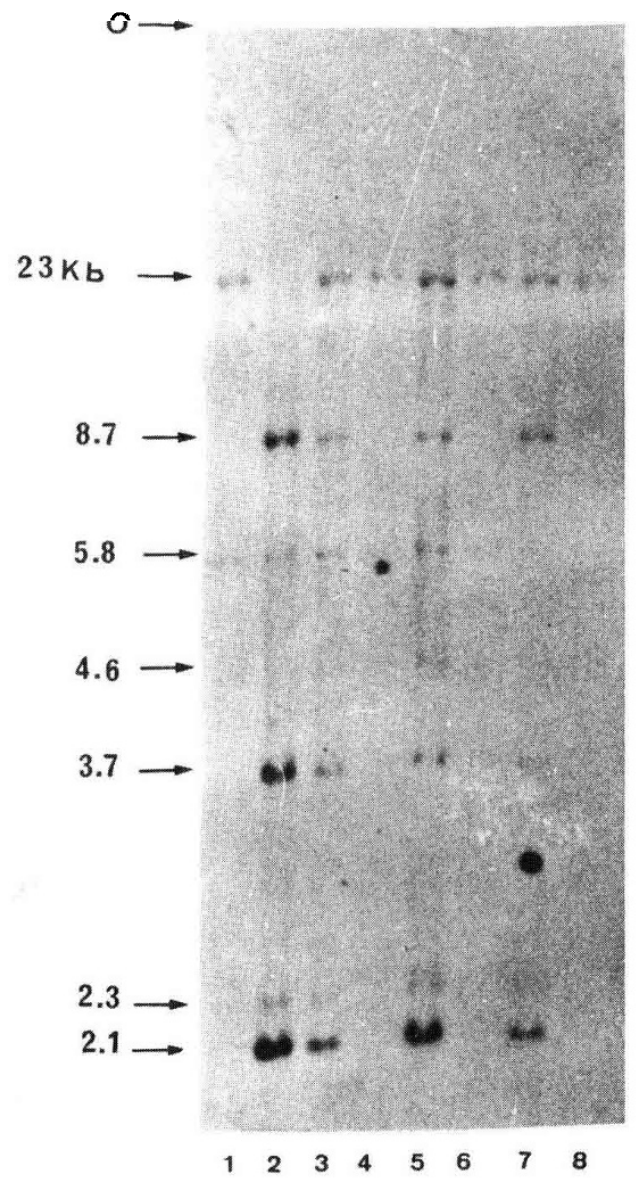

Fig 2. Hybridization of radioactive human OTC cDNA probe to EcoRI fragments from DNA of the Chinese hamster cell line (1); ovine lymphocytes (2); hamster $\times$ sheep hybrid lines grown in HAT medium $(3,5,7)$; hamster $\times$ sheep hybrid lines grown in 6 -thioguanine medium $(4,6,8)$. 
In this study, we showed two new syntenies for the sheep: GAPD-LDHBPEPB-TPI on chromosome 3 and ITPA-ADA on U15. The assignment to the $\mathrm{X}$ chromosome of 5 genes, known to be X-linked in several other species, confirms the concept of the conservation of the $\mathrm{X}$ chromosomal genome in mammalian vertebrates.

\section{ACKNOWLEDGMENTS}

We are grateful to AL Horwich, J Nathans, A Dautigny, LJ De Gennaro, U Rapp and K Wiman for their generous gifts of probes.

\section{REFERENCES}

Berman EJ, Nash WG, Seuanez HN, O'Brien SJ (1986) Chromosomal mapping of enzyme loci in the domestic cat: GSR to C2, ADA and ITPA to A3, and LDHA-ACP2 to D1. Cytogenet Cell Genet 41, 114-120

Bootsma D, Ruddle FH (1978) Report of the Committee on the Genetic Constitution of Chromosomes 2,3,4,5,7,8,10,11 and 12. Cytogenet Cell Genet 22, 74-91

Dautigny A, Alliel PM, d'Auriol L, Pham-Dinn D, Nussbaum JL, Galiber F, Jolles P (1985) Molecular cloning and nucleotide sequence of cDNA clone coding for brain rat myelin proteolipid. FEBS Lett 188, 33-36

Hopkinson DA, Povey S, Solomon E, Bobrow M, Gormley IP (1976) Confirmation of the assignment of the locus determining ADA to chromosome 20 in man: data on possible synteny of ADA and ITP in human Chinese hamster somatic cell hybrids. Cytogenet Cell Genet 16, 159-160

Horwich AL, Fenton WA, Williams KR, Kalousek F, Kraus JP, Doolittle RF, Konigsberg W, Rosenberg (1984) Structure and expression of a complementary DNA for the nuclearcoded precursor of human mitochondrial ornithine transcarbamylase. Science 224, 10681074

Huebner K, Ar-Rushdi A, Griffin CA, Isobe M, Kosak C, Emanuel BS, Nagarajan L, Cleveland JL, Bonner TI, Goldsborough MD, Groce CM, Rapp U (1986) Actively transcribed genes in the raf oncogene group located on the $\mathrm{X}$ chromosome in mouse and human. Proc Natl Acad Sci USA 83, 3934-3938

Human Gene Mapping 9 (1987) Ninth International Workshop on Human Gene Mapping. Cytogenet Cell Genet 46, 1-762

Human Gene Mapping 10 (1989) Tenth International Workshop on Human Gene Mapping. Cytogenet Cell Genet 51, 1-1148

Imam-Ghali M, Saïdi-Mehtar N, Hors-Cayla MC (1987) Sheep gene mapping by somatic cell hybridization: synteny of PEPC, ENO1 and PGD. Cytogenet Cell Genet 46, 632

Kilimann MW, De Gennaro LJ (1985) Molecular cloning of cDNAs for the nerve-cell specific phosphoprotein, synapsin I. EMBO J 4, 1997-2002

Millot P, Saïdi-Mehtar N, Hors-Cayla MC (1981) Complexe d'histocompatibilité ovin (OLA) et marqueurs enzymatiques dans des hybrides hamster $\times$ mouton. I. Asynténie entre PGM3-ME1 et OLA. Ann Génét 24, 82-88

Nathans J, Thomas D, Hogness DS (1986) Molecular genetics of human color vision: the genes encoding blue, green and red pigments. Science 232, 193-202

Ruddle FH, Meera Khan P (1976) Report of the Committee on the Genetic Constitution of Autosomes Other than Chromosomes 1, 2 and 6. Cytogenet Cell Genet 12, 31-53

Saïdi-Mehtar N, Hors-Cayla MC (1981a) Sheep gene mapping by somatic cell hybridization. II. Synteny between pyruvate kinase M2 (PKM2) and nucleoside phosphorylase (NP) in domestic sheep. Ann Génét 24, 148-151 
Saïdi-Mehtar N, Hors-Cayla MC, Nguyen Van Cong (1981b) Sheep gene mapping by somatic cell hybridization, four syntenic groups: ENO1-PGD, ME1-PGM3, LDHBPEPB-TPI and G6PD-PGK-GALA. Cytogenet Cell Genet 30, 193-204

Saïdi-Mehtar N, Goossens M, Hors-Cayla MC, Rosa J (1987) Sheep gene mapping by molecular hybridization: ovine gamma-globin and enzyme markers. Cytogenet Cell Genet 46,686

Siciliano MJ, Fournier REK, Stalling RL (1984) Regional assignment of ADA and ITPA to mouse 2 (c1-ter). J Hered 75,175

Stalling RL, Siciliano MJ (1982) Assignment of ADA-ITPA-AK1 and AK2 to Chinese hamster chromosome. $J$ Hered 73, 399-404

Wiman K, Larhammar D, Clavesson L, Gustafsson K, Schenning L, Bill P, Bohme J, Denaro M, Dobberstein B, Hämmerling U, Kvist S, Servenius B, Sundelin J, Petterson PA, Rask L (1982) Isolation and identification of a cDNA clone corresponding to an HLADR antigen $\beta$-chain. Proc Natl Acad Sci USA 79, 1703-1707

Womack JE, Moll YD (1986) Gene mapping in cattle: conservation of linkage with mouse and man. $J$ Hered $72,2-7$ 